\title{
At home in the city: everyday practices and distinction in international student mobility
}

\section{Laura Prazeres}

School of Geography and Sustainable Development, University of St Andrews, St Andrews, KY16 9AL, UK

International students have been overlooked in geographies of 'home', yet this paper demonstrates how international student mobility offers unique insights that can advance our understanding of 'home' and belonging in the city. Drawing on photo-elicitation and mid-point and return interviews with Canadian students, this paper explores the everyday home-making practices of exchange students in urban centres in the Global South. It focuses on the ways in which international students create a sense of 'home' and belonging in their host city and how insider knowledge gained through local everyday practices is converted into cultural capital. It contributes to the literature by considering how home-making practices are implicated in spatial and scalar boundary-making processes for distinction. By illustrating through participants' photographs how students articulate 'home' using spatial and scalar markers, I examine how students tighten the spatial boundaries of 'home' to focalise and localise symbolic capital within the city. The findings further add to debates on im/mobility by demonstrating that students' distinguish their relative immobility during the sojourn from the mobility of travellers and tourists to legitimise claims of belonging as 'insiders' and of place-specific capital. The paper then concludes by considering how students are 'collecting homes' for distinction.

Keywords: International student mobility; home; belonging; cultural capital; everyday practices; distinction

\section{Acknowledgements:}

I would like to thank Katherine Brickell and Katie Willis for their comments on earlier drafts and three anonymous reviewers for their very insightful comments. I am also grateful to the students who took part in this study. This work was supported by the Social Sciences and Humanities Research Council of Canada (SSHRC) [\#752-2012-0127] 


\section{Introduction}

The spatial and practical aspects of home-making within mobility are central to the academic literature on geographies of 'home'. Mobility can challenge ideas of 'home' as much as 'home' can influence experiences of mobility (Nowicka, 2007). 'Home' and mobility should not be treated separately; rather, as Ahmed et al. (2003) argue, research should examine how the relationship between 'home' and mobility is constituted. Germann Molz (2008) explains that 'the question, then, is not whether home matters anymore amidst all this mobility, but rather how home matters' (original emphasis p. 326). From this perspective, this paper situates its inquiry and focus within mobile geographies of 'home'. It explores how international exchange students create a sense of 'home' while abroad and the ways in which ideas of 'home' and home-making practices intersect with current theoretical insights on international student mobility.

While much research on 'home' within an international context has been examined through the lens of transnationalism and translocalism with diasporic migrants, few studies have explored the concept of 'home' and home-making practices among international students. Experiences and meanings of 'home' have been discussed within intra-national student mobility (Hinton, 2011; Holdsworth, 2009; Kenyon, 1999; Holton \& Riley, 2016) but remain an underresearched area of study within international student mobility (for exceptions see Anderson, 2012; Collins, 2009). Yet, as this paper will show, international student mobility provides a unique context to expand scholarship on mobile geographies of 'home'. Waters and Leung (2013) point out that 'international students have been perceived as interesting and remarkable precisely because they are temporarily "out of place", away from and yet constantly evoking "home"' (p. 607). This paper therefore brings together two expanding areas of interest - mobile geographies of 'home' and international student mobility - to advance our understanding of young people's home-making practices during temporary sojourns abroad. It makes an original contribution to the literature by theorising home-making as distinction-making.

Based on mid-point and return interviews and photographs with 28 Canadian exchange students, this paper examines experiences of home-making within the context of student exchanges to the Global South ${ }^{1}$. Since mobility is inherently political and differentially determined by unequal power relations (Cresswell, 2010), the voluntary nature of international students' mobility signals an underlying privilege. Further reinforcing these power relations are the 'colonial spatial imaginaries' that underpin student exchanges to the Global South (Madge et al., 2009, p. 39). Thus, student exchanges to the Global South offer a novel context to explore young (Western) people's mobile experiences of 'home'. I aim to merge and advance debates on geographies of 'home' and international student mobility in three ways. First, I respond to Datta's (2011) call for more attention to the mundane everyday spatial practices of mobile individuals within urban spaces by illustrating how home-making within short-term educational sojourns is tied to familiar everyday places and practices and to the acquisition of cultural and symbolic capital within the city. Everyday practices here will refer to the ordinary, daily practices of local people in a particular place. Second, I demonstrate how participants' articulate 'home' using spatial and scalar markers. Building on recent work that spatially re-conceptualises 'home' at the scale of the city (Blunt \& Bonnerjee, 2013; Datta, 2011), I explore why and in what ways cities and urban spaces are projected as 'home' for exchange students.

Third, I draw on Desforges' (1998) notion of 'collecting places' by exploring how students are collecting 'homes' while abroad. While 'collecting places' is about long-haul travellers framing the Global South as a place that is 'collected' through their travels (Desforges, 1998), I focus on

\footnotetext{
${ }^{1}$ This paper adopts the term 'Global South' defined broadly by the United Nations Development Program (2004) as countries in Africa, Latin America, Caribbean and Asia with a range of different social, economic and political contexts but with a "shared set of vulnerabilities and challenges" ( $p$. 2).
} 
how exchange students who remain relatively immobile while abroad (i.e. sojourning in one city rather than continuously travelling onward to other destinations) develop a sense of 'home' within the host city that can be converted into a very specific scalar and localised type of cultural capital for distinction. As perhaps a reaction to global travel becoming increasingly unexceptional among young people in the Western world, exchange students may seek ways to diversify and rarefy forms of cultural and symbolic capital through specific spatial and scalar claims to 'home'. The next section highlights some central debates and concepts within 'home', belonging and international student mobility that underpin the analysis of the paper. I then turn to the methodology section before unpacking the verbal and visual narratives of students' homemaking in the Global South.

\section{Home, mobility and belonging}

Scholars note that conceptualisations and meanings of 'home' have shifted from fixed and stable to mobile and fluid (Nowicka, 2007; Rapport \& Dawson, 1998). While the concept has taken on a mobile definition, 'home' itself can be mobile and people can feel 'at home' in mobility (Germann Molz, 2008). Yet there is a need to explore home-making practices within the relative immobility of student sojourns abroad. Since Wiles (2008) argues that 'home and the idea of home structure the experience of migration' (original emphasis, p. 117), mobility and 'home' are thus considered to be mutually constitutive. 'Home' is no longer seen as a rigid entity but rather as a 'space in-becoming' (Nowicka, 2007) and an 'ongoing process' of home-making (Ahmed et al., 2003, p. 10). Home-making, in this sense, is a practice through which 'home' is made and remade as part of a process of (re)creating homely practices, spaces, and relationships (Blunt \& Dowling, 2006). 'Home' is a familiar environment and feelings of familiarity and local mundane practices are central for creating a sense of 'home' (Nowicka, 2007; Wiles, 2008). Since people transpose and enact feelings of comfort and familiarity 'through various embodied practices', 'home' can be re-created in different places and within mobility (Germann Molz, 2008, p. 329).

While this study considers familiarity and local everyday practices as key to home-making practices, it critically examines and extends this approach to students' sense of belonging to their host place. It also considers how social interactions and relationships influence feelings of 'home' and belonging during sojourns abroad. For example, in his study on the influence of journeys away on the meaning of 'home', Case (1996) reveals that participants discovered the conceptual boundaries of 'home' to be centred on social relationships and routines. By engaging in daily routines in a new environment, 'these patterns and places become intimately familiar, so much so that they are unconscious to our daily routine, yet their very familiarity and routineness is what evokes the sense of "being-at-home"' (Case, 1996, p. 3). Scholars indicate that meanings of 'home' are embedded and constructed in everyday life (Blunt \& Dowling, 2006; Valentine, 2001) and in seeking to understand how mobile individuals created temporary homes within mobility, Nowicka (2007) points to the importance of routine practices and the 'repetition of habitual interactions' for familiarity and home-making (p. 72). As repeated encounters with local people can bring about homely feelings, Wiles (2008) points out that migrants in London repeatedly ascribe meanings of 'home' to social relationships, 'familiarity with a place and with local ways of doing things' (p. 134).

However, much of this focus on social relationships is linked to family members and travelling companions whilst less attention has been given to the influence of local people on international students. This paper therefore examines the role of members of the local society for mediating feelings of belonging and 'home' during sojourns abroad. I explore how creating a sense of 'home' depends in part on the inclusion and integration of individuals into the local (Kellett \& Moore, 2003). Feelings of belonging can be self-defined but also socially determined in that belonging depends to a certain extent on recognition from the local community (Ralph \& 
Staeheli, 2011). The process of home-making is intimately tied with a sense of belonging (Ralph \& Staeheli, 2011) and much like critical geographies of 'home', belonging is implicated in practices of inclusion and exclusion (Gilmartin, 2008) as well as boundary-making (Yuval-David, 2006).

'Home' is both a place and a feeling (Blunt \& Dowling, 2006) and feelings of belonging can also be tied to a place. I take Skey's (2011) conceptual point that "it is primarily through boundary-making processes that particular places come to be (seen as) identifiable, familiar and secure" (p. 238) in order to explore the relationship between familiarity, home-making and belonging. Antonsich (2010) describes belonging, and more specifically place-belongingness, as a 'feeling of being "at home" in a place' that is tied to familiarity and comfort (p. 645). Despite the prominent relationship between familiarity and 'home', scholars both recognize and critique conceptualisations of 'home' as familiar (Ahmed, 1999; Mallett, 2004). Ahmed (1999) underscores the ubiquity of strangeness in the home nation and argues that migration is movement between estrangements. While I acknowledge these critical perspectives, I concur with Mallett (2004) that 'home' can be both familiar and strange. This apparent contradiction is pertinent to my study on international mobility, since migrants and mobile individuals are considered strangers in a new place, yet they create a sense of familiarity that feels homely among greater conditions and instances of unfamiliarity and strangeness.

Since people can feel 'at home' and a sense of belonging at varying scales, ideas of 'home' can also be conceived at a larger and more abstract geographical scale than the nation. Some travellers such as global nomads develop a sense of at-homeness in the world and consider the globe as 'home' (Ahmed, 1999). In viewing themselves as 'world citizens', long-term travellers in Germann Molz's (2008) study use this imagined global self as a way to distinguish themselves from tourists and, in the process, invariably end up reproducing 'a privileged cosmopolitan appropriation of the world' (p. 338). Leaving 'home' and crossing international borders can thus reproduce privilege as much as it can reinforce or dissolve a sense of belonging along specific spatial and scalar boundaries. From this point, I advance scholarship by investigating how narratives of 'home' and belonging through international mobility are implicated in processes of boundary-making and distinction-making.

Contrary to theoretical and empirical work that conceptualises 'home' at the level of the nation (Skey, 2011; Wiles, 2008), I explore how scalar boundaries of familiarity and homemaking are enacted within the city. Recent works on migration and 'home' frame the 'city' as a homely place (Blunt \& Bonnerjee, 2013; Datta, 2011; Lahiri, 2010). In exploring the local-global dialectic and fluidity of belonging, Lahiri (2010) highlights how migrants feet 'at home' in the city through their narratives of urban belonging. Similarly, Blunt \& Bonnerjee (2013) demonstrate that, despite references to India as 'home', members of Calcuttan diasporas attached a sense of belonging and homeliness to Calcutta as their city of birth. Calcutta is remembered as 'home' through memories and mundane practices, but it is also a site of belonging and urban identity. Everyday urban spaces and practices are vital to home-making and an urban sense of belonging is very much tied to familiar everyday practices and 'embracing an urban way of life' (Blunt \& Bonnerjee, 2013, p. 237).

The focus of this paper, accordingly, falls on how everyday practices are deployed by exchange students as a way to create a sense of 'home' and belonging in their host city, but also to accumulate what Cook (2011) has termed 'place-specific capital'. Datta (2011) demonstrates not only how migrants' everyday practices create a sense of 'home' and belonging at the urban scale, but how migrants assign different types of cultural and symbolic capital to the places they have previously lived and to the different neighbourhoods in their city. Migrants, then, seem to define particular urban spaces as unique and distinct from other areas of the city in order to accrue specific forms of cultural capital. Social networks cultivated in a new place can lead to the accumulation of place-specific capital; that is, local knowledge of a place which includes everyday practices and cultural ways of life (Cook, 2011). Whereas 
migrants in Cook's (2011) study gradually developed local everyday practices over time through social networks that enabled place-specific capital accumulation, I examine conversely how everyday home-making practices are used to acquire cultural capital specific to (areas within) the city. However, since these studies and most of the work on 'home' and the city are focused on diasporas and migrants within a transnational and translocal perspective, this paper extends the literature by examining an internationally mobile student cohort.

\section{Symbolic capital and international student mobility}

This paper not only explores the practices deployed by short-term exchange students for homemaking, but also the strategies for accumulating cultural capital towards distinction. Thus, it advances our understanding of how practices of home-making constitute and intersect with symbolic capital and distinction-making within international student mobility. Research on young people's travel demonstrates how being (voluntarily) internationally mobile affords travellers with valuable cultural capital for distinction. By accumulating cultural capital through travelling, young mobile people enter into a competition for distinction with other travellers. 'Collecting places' through mobility allow travellers in Desforges' (1998) study to express an authority over a particular part of the world - i.e. the Global South - that distinguishes them from non-travellers back home. Indeed, Desforges (1998) explains that 'by using travel as a form of cultural capital which serves as a sign of distinction, travellers gain access to a social class and its consequent privileges' (p. 185). Collecting experiences in the Global South acts as a marker of achievement and difference (Munt, 1994) and affords greater prospects for employability upon return (Breen, 2012). Travel to places viewed as less consumed by mass tourism enables travellers to differentiate themselves from tourists and achieve social distinction (Munt 1994).

Since leaving 'home' to travel denotes a form of privilege for travellers, then international student mobility also indicates a possession of beneficial qualities and resources that enable young people to participate in sojourns abroad. Much of the literature on international student mobility expounds the relationship between student motivations and acquisitions of cultural capital (Findlay et al., 2012; King et al., 2011; Waters, 2012). Studies demonstrate that the acquisition of cultural capital through international mobility enables individuals to achieve a mark of distinction (Findlay et al., 2012). Indeed, Findlay et al. (2012) indicate that students from independent schools in the UK chose to attend a 'world class' university abroad to accrue cultural and symbolic capital as a way to distinguish themselves from 'home' students in the labour market. This cultural and symbolic capital can then be converted into economic capital upon return. Young people anticipate the needs and requirements of potential future employers and therefore engage in the pursuit of distinction through an international education and a range of activities therein to acquire the 'right' credentials that might make them stand out among a competitive and saturated labour market in the 'home' country (Brooks et al., 2012). Yet, much of the work theorising cultural capital within international mobility is drawn from degree-seeking students, with fewer linkages made with shorter-term mobility students.

However, some students pursue studies overseas for more leisurely considerations. Much like the escapism of travel and tourism, an overseas education can also serve an adventurous purpose, offering personal - rather than necessarily a professional - enrichment (Waters et al., 2011). In their study of UK students abroad, Waters et al. (2011) demonstrate how an international education is combined with a desire for adventure and excitement. Despite what may appear as a more laissez-faire approach, the pursuit of 'fun' and 'happiness' can entail inevitable - but not always intentional - social reproduction of advantage (Waters \& Brooks, 2010). Since most internationally mobile students already possess various forms of advantageous capital prior to their international education (Murphy-Lejeune, 2002), the mere fact of studying overseas reproduces this privilege (King et al., 2011; Waters, 2012). 
International student mobility can therefore entrench young people's membership within an exclusive and distinctive club (Waters \& Brooks, 2011).

\section{Researching the visual geographies of 'home'}

This research is part of a larger qualitative longitudinal project on short-term student mobility to the Global South in which semi-structured interviews were conducted with Canadian university students at three stages: pre-departure, in situ at the mid-point, and upon return to Canada. This paper however draws only on mid-point and return interviews in order to understand international students' home-making practices while abroad. A total of 28 participants took part in the study - 24 women and 4 men $^{2}$ - with 13 participating in a study exchange at a university in the Global South and 15 in an internship placement with a non-governmental organization in the Global South. Sojourn lengths ranged between 2 months and 12 months and the host cities were located in Latin America and the Caribbean, Africa and Asia. I recruited participants at predeparture orientation sessions at Canadian universities in Ontario and Québec (between March 2012 and May 2013) and thus, both Francophone (12) and Anglophone (16) students are represented in the study. While interviews were conducted in French and English according to participants' preference, all quotes were translated into English. I have retained in brackets and italic some original French expressions or words since, as Antonsich (2010) highlights, the translation of the term 'belonging' in English does not carry the same connotation in French. All names have been changed to maintain anonymity. The audio-recordings of the interviews were transcribed and a thematic analysis was used to identify meanings and themes around students' home-making practices and sense of belonging while abroad.

Since documenting one's travels with photos on Facebook and Instagram is prevalent among young people, the decision to use participant-directed photography as part of this study was both a relevant and productive choice. Visual methods offer a unique and dynamic insight into people's perspectives on place and ways of seeing (Pink, 2006; Rose, 2008). Photo-elicitation was combined with the final return interviews to prompt participants to reflect on their experiences of place and events while abroad. Photo-elicitation allows participants to illustrate the subjects most meaningful to them whilst leading the interview discussion on those topics. Since, as Dodman (2003) explains, urban life is an intense visual experience, photographs have been useful for illustrating participants' sense of 'home' in the city. Indeed, participant photography is commonly used within studies of home-making (Datta, 2011; Holton \& Riley, 2016). Photographs allow a 'unique (insider) perspective' into participants' lives (Pauwels, 2011, p. 8) and hence, the opportunity to describe their photographs offered participants a chance to narrate their insider perspective of their host city.

Participants were given instructions to take photos during their sojourn with a particular emphasis on the places they regularly frequented. Upon return to Canada, they were asked to select around 20 photos that they felt best represented their experience and the places that were most meaningful to them. While photography is a great tool to see through participants' eyes, my vision is nonetheless filtered through a different lived/personal lens than theirs, and since the purpose of using participant photographs was to prompt and elicit information as part of the final return interviews, I did not analyse the photographs independently from the verbal descriptions. The intention was to understand the content of the photographs from the participants' perspective and therefore interpret and analyse their descriptions rather than make assumptions. The next section dives into the everyday urban places and practices that constructed participants' sense of 'home' and belonging while abroad.

\footnotetext{
${ }^{2}$ The overrepresentation of women in this study reflects higher female participation rates within study abroad programs in the Western world (Salisbury et al., 2010)
} 


\section{Insider knowledge and urban belonging}

\section{Everyday places and practices}

Upon arrival in their host destination, participants' set out to explore and become familiar with their new city in order to create a sense of 'home' and become a local insider. 'Home', as Ahmed (1999) notes, is a 'knowable terrain' (p. 337) and participants are eager to know its streets, commercial places, and social hubs in order to feel 'at home' while abroad. During her study exchange in Santiago, Chile, I asked Valérie what makes Santiago or her neighbourhood feel like 'home'? She explains:

The fact that I had been in those streets many times, I know where to go by bike because I've passed there many times. The fact of repeating certain everyday life practices (styles quotidiens), of going to that boutique to buy everything. I was no longer on my guards. Ya, I knew the beat of the city.

Valérie demonstrates how feelings of homeliness developed alongside a growing sense of familiarity with local practices and spatial knowledge of the city. Part of feeling 'at home' is about knowing the 'beat of the city' or, as Wiles (2008) notes, it is about knowing the 'rhythms' of a place (p. 123). To illustrate this sense of 'home', she shared a photo of her street in Santiago:

Figure 1. Valérie's street in Santiago, Chile

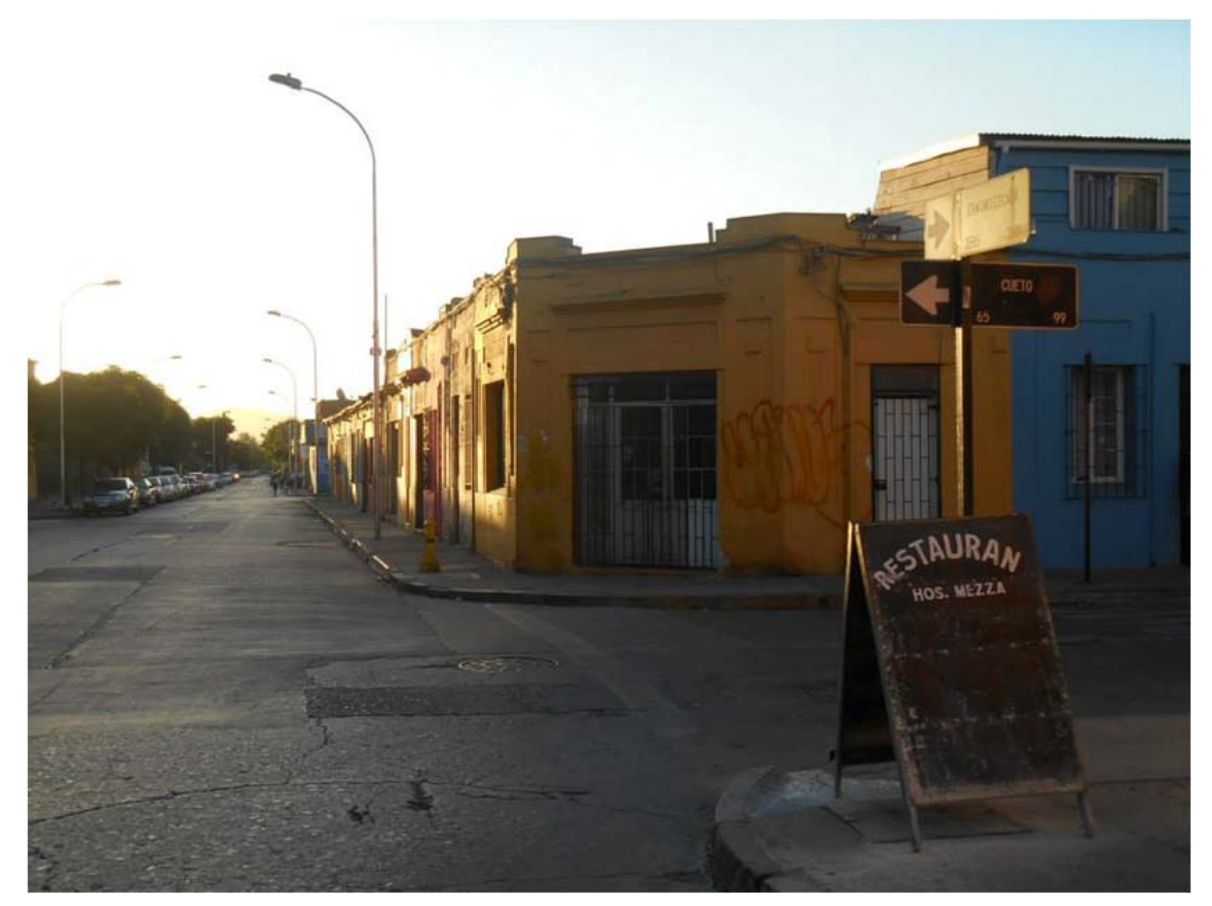

This is my street. ... This street was always calm because it's a residential neighbourhood but I live on the street where you see 'cueto' [see street sign] in perpendicular. And I put this [photo] because that's where I passed on my bike or that's where I would go to take the bus, stuff like that, so it's really my neighbourhood. 
Valérie emphasises in her tonality that this is her neighbourhood through living, biking and walking through its streets. As a temporary newcomer, her comment obscures the locals that have spent a greater part of their lives in these streets and may feel differently about its space and her presence within it. Camille, a Francophone student on a 5-month study exchange in Buenos Aires, recalls the moment when she felt 'at home' in the city:

I was at ease (à l'aise), I felt 'at home' (chez moi) from the moment where I understood how it works, how you stop the bus. There was an awkward moment where you really look like you're not from the place. You don't know how it works, how to buy vegetables ... but after that, you know, I felt 'at home' (à la maison).

Camille recounts the process of transitioning from being 'awkward' and 'out of place' to knowing the everyday workings of the city and feeling 'at home'. The awkwardness Camille and other participants refer to relates to feeling 'out of place' in a new environment, of not yet knowing the everyday local life, of not yet being an insider. Much like how travellers' in Snee's (2013) study 'negotiate potential embarrassments by gaining insider knowledge' (p. 151), Camille dealt with the 'awkward moments' by observing and adopting the practices of locals in Buenos Aires. While these practices are habitual and unreflexive to locals - e.g. knowing how to stop a bus and buy vegetables - participants want to learn these local differences to avoid appearing 'out of place'. Much as Edensor (2007) argues that travel is often enmeshed in everyday life and largely unreflexive, I have suggested elsewhere that it is local people's unreflexivity within everyday practices which exchange students want to develop in order to become local insiders abroad (Prazeres, 2016). Valérie explains this further:

Those small practices make me feel a bit like I too am part of that city and that life. Just to be able to know what are the small things that I need to say in Spanish - but in Chilean Spanish - at which moment and to whom, you know; I have the impression that I'm part of that world and to be able to show them that even if I look foreign (étrangère), I know the everyday life (les quotidiens), I know how it works ... I feel settled.

For Valérie, engaging with these practices and routines in her new city imparts a sense of belonging to the local urban life. Getting to know the physical and social landscape of the city allows her to peer into the deeper layers of the mundane social fabric of the city and understand local customs and insider life. This, in turn, gives her a sense of 'home' and belonging. Yet, her comment of wanting to 'show them' - presumably, local Chileans - her knowledge of everyday life suggests that she seeks to both showcase to, and receive recognition from, the local community to which she aspires to belong. As Murphy-Lejeune (2002) highlights, 'what is at stake in this social game is integration into the local society' (p. 196). Indeed, as the next section will show, acceptance or acknowledgement from locals in the community is the ultimate indication of what participants regard as a successful immersion into local everyday life.

\section{Locals and locales}

Active participation in everyday life offers participants an opportunity to become familiar with particular places and recognise specific people and, conversely, the people in these places recognise them through their frequent or repetitive visits. Living with locals in a shared house in Santiago, Elodie chatted with me about feeling 'at home' in the streets of her city:

I feel a little like 'at home' (comme chez nous). These are places that integrated me to the city and it's like there is a little bit of me in these streets. I feel good and I pass in front of certain corner stores and there are people that recognise me, you know, and then they smile, 
and I feel (pauses) not 'at home' - I know I'm a foreigner and I always will be - but a little bit, it's like 'home' (laughs).

Elodie demonstrates how becoming familiar with places and a simple, small gesture of recognition from locals (such as a smile) can impart feelings of belonging and homeliness. Repeated visits to everyday places foster a sense of familiarity and inclusion between participants and locals. This sense of knowing the spatial and social everyday landscape of a new place affords participants with a newly acquired sense of insiderness. Local belonging is emphasised through their insider knowledge of their new place and their relationships with local people (Benson, 2010). Céline illustrates this sense of familiarity with an elderly woman who lives and works next to her place in Peru (see Figure 2):

Figure 2. Céline's Peruvian 'grand-mother'

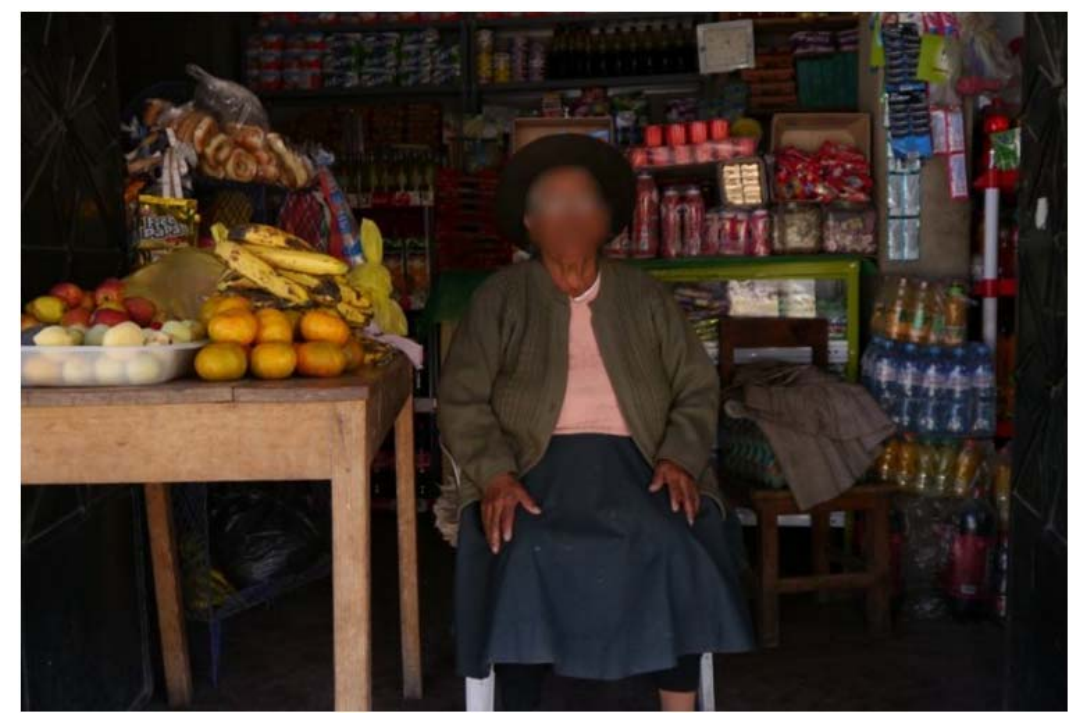

That was my Peruvian grand-mother (laughs). ... I had such difficulty to understand her because she spoke Spanish but interspersed with the native Quechuan tongue, so it was incomprehensible, but she would always say to me 'my pretty, my pretty, good day, good day!' and it would end there. But we saw each other all the time during the day. So ya, it was a lovely encounter (une belle rencontre). ... she was a bit of a cornerstone (un monument) for the community, always there, she knew everyone.

Céline's reference to her Peruvian neighbour as her 'grand-mother' is both an endearing term as well as an attempt to appropriate an esteemed local figure of well-placed social standing as 'family' and thus, as familiar. Despite the limited and superficial interaction between them, Céline wants to not only show her familiarity of local people, but that the locals themselves acknowledge and even seem to welcome her presence in town as perhaps evidence of her immersion in the urban community. This daily pattern of attention she received from a woman who is a cornerstone in the community seems to be used by Céline to suggest her status - at least temporarily - as a 'local' in her host neighbourhood. Participants want to become familiar with local places and people but they also want to become familiar to local people.

Locals and locales were instrumental in negotiating and developing a sense of 'home' and belonging to the urban community. Marie-Josée, who lives in a shared house with a mix of locals and international students, describes how local places contributed to feelings of belonging while in in her host city in South Africa: 
I felt like I was integrated because these are small hidden places that only the locals know ... So I have the impression that I am from the place. I sit down and people talk to me directly in Afrikaan. Generally people speak to me in English because I don't look like I'm from here, but I arrive in these places and the people speak to me in Afrikaan, ... So I really have the impression that I am a South African citizen in a tranquil café. I like that, because I don't have the impression that I am with a gang of internationals that speak tons of languages and just look like tourists.

Marie-Josée explains how she seeks out 'ordinary' places that are not in the tourist itinerary; places that are frequented predominantly and ideally uniquely by local citizens in order to feel like she not only 'fits' in the place but is from the place. In this case, Marie-Josée excludes not only tourists from her imaginary of the 'local' landscape but also other international students such as herself. In wanting to avoid being exposed as someone 'not from the place' - and potentially 'out of place' - she visits the café independently from international students in order to uphold her image as a local (but also national) 'citizen'. For Marie-Josée and other participants, having local people address her in the local language is an affirmation that she could be, or at least appears to be, from that place. Indeed, as a tall, fair-skinned girl with lightcoloured hair, Marie-Josée has similar features to those of local - and privileged - Afrikaners. Thus, through the privilege of her 'white' appearance, she can easily feel 'at home' in South Africa - potentially more so than other 'non-white' locals. Being mistaken or able to pass as a local is the ultimate marker of belonging for many participants and the utmost indication of integration and cultural capital accumulation. Although bodily features rather than any particular skill or acquired cultural competency are at play in the social game of integration, it is also her very presence in this particular locale that contributes to assumptions of her nativeness. Lucy adds to this during her study exchange in Ankara, Turkey:

You definitely feel like you're part of it. You become more of an insider as opposed to a tourist. Actually, a lot of people think I'm Turkish here even though I have light skin, but I have dark eyes and hair, so people come up to me and think I'm the Turkish one of the group. And now that I'm able to get on the bus and know where I'm going it makes me feel like people don't look at me differently. Before I felt like people were looking at me like, 'oh, she's foreign' and that makes me a little bit uneasy, but now that I'm more comfortable and assertive in where I'm going, I just feel a lot more part of the - not necessarily the Turkish society - but at least the area.

Lucy demonstrates how comfort in navigating local transportation and being mistaken for a Turk generates feelings of belonging and of 'insiderness'. Yet, while describing these feelings, she catches herself mid-sentence and seems to steer her claim of belonging from the nation of Turkey to that of the local area. Lucy may have hesitated to express a national sense of belonging in realising that an overstatement may undermine her credibility and claims of being an 'insider'. Despite having fair skin, Lucy's darker facial features allow her to blend in the social landscape and pass as a local. Indeed, Marie-Josée and Lucy's appearances within the ethnic contexts of their places facilitate their integration into the local society and in doing so, situate and construct their experience differently than those of other fair-skinned participants in countries where the ethnic majority has characteristically darker skin. Nevertheless, Lucy highlights the importance of familiar local places and people for feelings of homeliness:

There's one coffee shop that I go to a lot and the waiters know us there, even though they know we don't speak Turkish, you just feel really relaxed... it just makes me feel like I'm 
welcomed because they know what you're going to get and so you just feel really included in society.

Although participants seek out and patronise more local shops and places in order to distance themselves from tourists and to be recognised as locals, they often do so in the company of other international students. Yet, participants feel as though they are acknowledged as 'locals' and 'insiders' because of their frequent visits to the same places and their familiarity to the locals who work there. Participants look for cues from locals - a nod, a smile, a greeting from the waiter that recognizes them - that could indicate their integration into the local society. By establishing routine jaunts and haunts in the city, they develop informal relations with locals and intimate relationships with places that provide a sense of 'home' and belonging. A sense of belonging to a place develops not only through familiarity, but also depends on 'the extent to which others recognise us as legitimate participants in that setting' (Anderson, 2012, p. 332). Through repeated encounters and daily interactions with local places and faces, participants feel they have established a connection, even if limited, with local people that provides them with a sense of 'home' and belonging in the city. However, the voluntary nature of their mobility means that there is always comfort in knowing that the sojourn abroad is a choice with an expected return. Unlike the South-North and South-South mobilities of other migrants where fraught circumstances may hinder feelings of 'home', participants' underlying privilege is what enables them to feel 'at home' abroad.

Although some students project a claim of belonging to the nation, others seek to strategically tighten the spatial boundaries of 'home' to the city or neighbourhood in order to localise accumulated cultural capital. The next section will show how participants delineate a sense of 'home' at the scale of the city as part of a strategy to visually and verbally narrate a place-specific cultural capital (Cook, 2011).

\section{The city as 'home'}

Among the narratives of 'home' and belonging there stands out a specific spatial scale of homemaking. Contrary to theoretical and empirical work that conceptualises 'home' at the level of the nation, the majority of my participants frame their host city as a homely place. For example, Sophie shows off her host city as her 'home' during her 3-month internship in Guatemala (see Figure 3): 
Figure 3. Showing off the city of Antigua as their 'home'

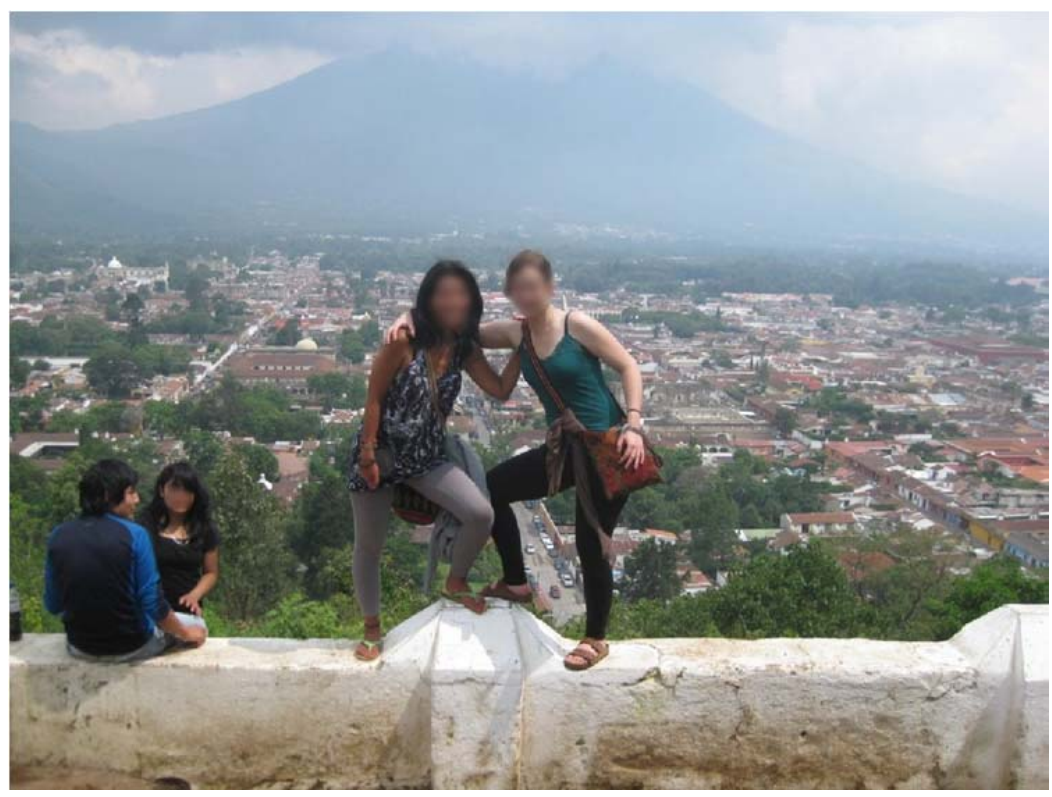

The picture is myself and my friend Mitsu from Japan. So this is us just kind of standing on the edge of a concrete barrier, and we're like, 'that's our city!' you know, like, 'that's our home!' and were just so happy and having a good day together. So ya, that's just a photo showing off our houses.

Sophie is effusively proud in 'showing off' the urban space of Antigua with her friend as their new 'home'. This photograph is illustrative of how exchange students, like Sophie and her friend, attach a sense of 'home' and belonging to the space of the city, rather than to the nation (Lahiri, 2010). Since familiar spatial qualities are located and localised through a process of boundary-making (Skey, 2011), by delimitating urban spaces along imaginative and administrative boundaries, the 'city' is encompassed and projected as 'home'. Unlike much work that defines the nation as a homely place, my study suggests a scaling down of 'home' to a more knowable and relatable space of urban locality (Datta, 2011). My study chimes with Blunt and Bonnerjee's (2013) work in exploring the city as 'home' 'through the observation of familiar everyday urban practices' ( $p, 226)$. Similar to their respondents, my participants attribute familiarity to everyday places and practices in their host city as a source of homely feelings. While not illustrated here, participants also referred to their Canadian hometowns as 'home' rather than Canada as a nation. This is not to suggest that cities are exclusively seen as the only homely place or scale; rather, in comparison to other scales, urban centres are predominantly identified as 'home' among this cohort.

Judy demonstrates this urban sense of belonging through one of her photographs that depicts wall graffiti in the northern part of her host city (see Figure 4): 
Figure 4. Graffiti of 'Chiclayo Norte' - a neighbourhood in Peru

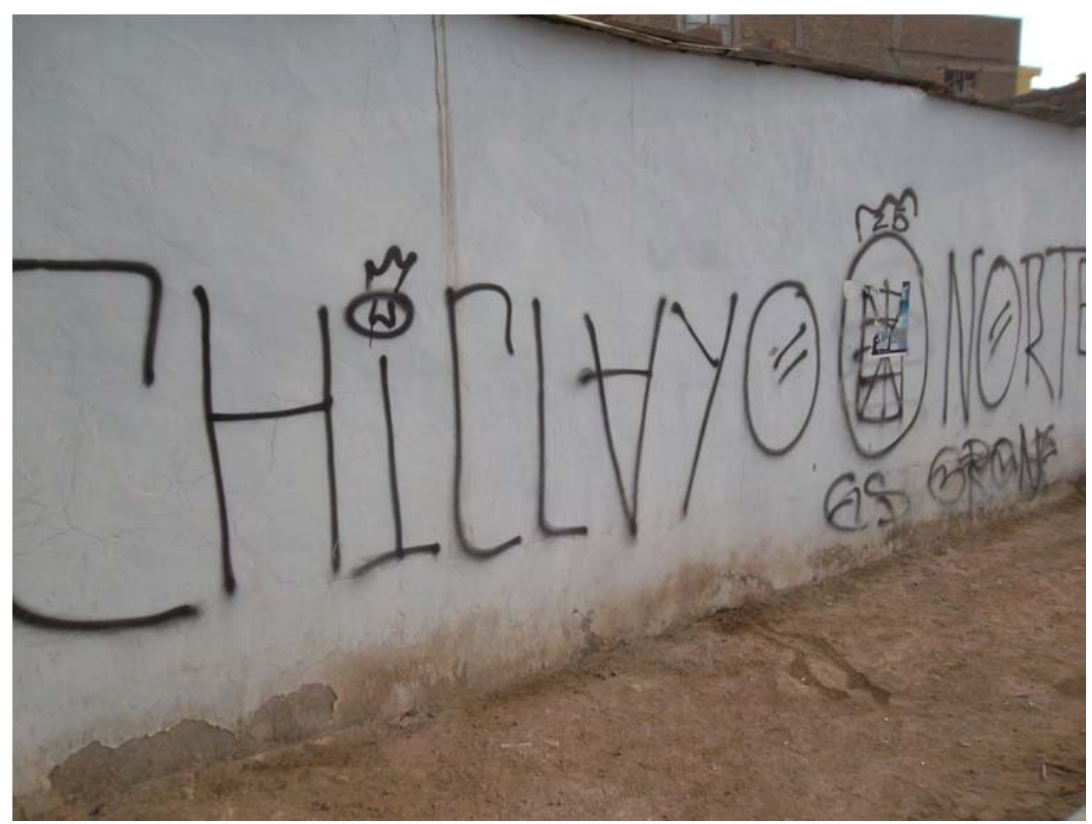

This picture represents, like, it's sort of in a bad area of town, so I'm like: 'this is my neighbourhood man, these are my people, this is my hood!' I've always loved being in the North, which is funny because I live south of the actual city of Chiclayo. I don't live in the city really, but I like to consider myself Chiclayan and so I saw the picture and I'm like, 'ya, graffiti!'

This is an apt example of how participants attach a sense of belonging and 'home' to a more localised scale of the city (and neighbourhood) instead of the nation. Judy's slang references to this graffiti scene in Chiclayo Norte as her 'hood' and her 'people' are partly said in jest, yet they do illustrate how she claims a sense of belonging to its local community and urban space despite admitting that she does not reside in that part of town. Describing this neighbourhood as a 'bad' part of town seems to appeal to, and coincide with, the popular perception of places in the Global South as risky and dangerous and may underscore an attempt by Judy to acquire a particular kind of local cultural and symbolic capital that might make her appear more edgy and street-wise. Indeed, through its popularity and postcolonial imagery as a 'poor' place, the Global South tends to be associated with higher gains of cultural and symbolic capital. Similarly, Valérie's focal sense of 'home' during her study exchange in Santiago was her neighbourhood:

I was at a point where I knew my neighbourhood well, the neighbourhood was really my 'home' (c'était vraiment chez moi), you know. I didn't really leave my neighbourhood much. I did everything by foot or on bike, you know. Most of the exchange students weren't there but my close friends often lived in that neighbourhood.

Valérie suggests that by limiting her mobility to walking and biking, she intentionally concentrated her activities and home-making practices within the surroundings of her immediate neighbourhood in a way which endowed her with a sense of 'home' and insiderness. As such, for some participants, a sense of 'home' and a claim to local belonging may very well be focused within a smaller scale than that of the city. Noting the apparent absence of other international students in her neighbourhood, Valérie can suggest that the bar retains a sort of local cachet, which affords a very localised and place-specific type of cultural capital. 
I argue that home-making through everyday practices and places is also a process of spatial boundary-making for symbolic capital and thus, distinction. Rather than make a grand claim of being a Peruvian or Chilean (or any nationality) which would be quickly discredited by others, many participants seem to downscale their claims of belonging to that of the city or neighbourhood. I therefore suggest that the cityscape or city space affords a more practical and conceivable geographical area to develop a sense of familiarity and geographical knowledge in order to lay plausible, if not credible claims of 'insider' and 'local' status. Participants are not so much attempting to pass as national citizens in their host country (even if some do try), but more to become local 'cityzens' as a way to claim a rarer and place-based form of cultural capital that can be narrated upon return. The next section continues along this thread by demonstrating how students seek to 'collect homes' by drawing a distinction between their living status and the visiting purpose of tourists and travellers.

\section{Distinction through home-making and 'living' abroad}

Now comfortably settled in her new 'home', Christina describes how she has acquired the knowledge of the city that she recalls pinning for during our pre-departure interview. In fact, she even discusses her new collection of homes:

So the way I think about it, I have three homes. I have lived in Ottawa, I have Dar and I lived in my hometown. I'm collecting homes, kind of, you know? So it's pretty awesome, because I know I remember saying to you at the very beginning [during our pre-departure interview] is that the reason I'm going for a full year instead of half a year is because I wanted to know some place like the back of my hand, and I actually really distinctly remember that and the truth is that now I do.

Christina points to the 'homes' she has collected between Tanzania and Canada through the length of her sojourn and her specific spatial everyday knowledge of these cities. This reflects Desforges' (1998) study of travelers in which the notion of 'collecting places' is a means of framing the Global South 'as a place where individual knowledge and personal experience can be gained through travel' (p. 183). However, instead of collecting the Global South as a place, participants in my study - like Christina - are 'collecting homes' within the Global South through their insider knowledge of their cities. With increasing travel and voluntourism to that part of the world, I suggest that short-term international students are finding localised and focalised ways of accruing more unique forms of cultural capital within the Global South. Cities and urban locales are seen to offer localised types of cultural capital which can be collected through local everyday practices. Rather than just a place to be visited and travelled through, host cities and neighbourhoods are collected as 'home' through residing and studying or working. The length of stay and relative immobility of their sojourn allows students to develop relations with locals and locales (even if superficial) in a way that accumulates a specific type of cultural capital. Just as 'collecting places' requires young people to engage in travel practices used 'to authenticate their knowledge and experience' and visiting places that are for locals rather than for tourists (Desforges, 1998, p. 181), so too does the idea of 'collecting homes' require students to participate in everyday practices in places that are ideally frequented solely by locals in order to develop a sense of belonging and gain insider knowledge. Insider knowledge can thus be converted into place-specific cultural capital. That is, this 'collection' of 'homes' signals an accumulation of a more localised cultural capital that can be narrated to friends and family.

'Home' and cultural capital are not only narrated in terms of claims to multiple urban 'homes' (or 'cityzenships'), but in drawing a distinction between living and visiting in the city. Christina voices a common sentiment among participants: 
I think 'home', it evolves. It's wherever, because I really do think that I have three homes. I think it's a feeling and ... it's just a sense of knowing a place and feeling like you're not just visiting, I think. Because I don't feel like I'm visiting. I feel like I'm living here and I'm experiencing here and the word that I really use is 'established', I'm established here.

Knowledge of the place still underscores Christina's homely feelings but she also justifies her appropriation of her current place as 'home' by emphasising her 'living' rather than 'visiting' status. Through repeated use of the term 'established', she does more than describe her condition as settled and knowledgeable of everyday life; she is also referring to her new position as an insider. She continues:

What I tried to do is live, instead of watch. ... I wanted to come for a whole year so that I know somewhere and I can say that I lived there, and I can legitimately say that I lived in Dar. I know Dar, I know how much certain things should be, taxis from place to place, even what's reasonable, what wouldn't be, where I should pick my spots and choose my battles, I know the bus routes and how much piki piki motorcycles should be. It just feels so cool, you know. I'm my own type of expert on this place in my experience.

Christina and other participants are adamant in underlining and asserting their living rather than visiting purpose abroad and their local as opposed to tourist status. There seems to be an assumption or perception among participants that the studying or working purpose of their sojourn allows for and legitimatises claims of insider knowledge. Through her self-described everyday insider knowledge of the city, Christina can present herself as not only an insider, but also an 'expert' on the place to family and friends in Canada. She seems to attempt to gain symbolic recognition from her peers by clearly distinguishing her sojourn as an everyday studying and 'lived' experience in Dar es Salaam rather than as a tourist sightseeing trip. As such, participants not only delimit spatial and scalar boundaries for home-making and cultural capital, but also draw a distinction and contextual boundary between 'living' and 'visiting'. Here, Amy explains this 'lived' difference in Lima, Peru:

I'm living somewhere as opposed to just visiting it ... I've traveled before, I've been away to other countries and developing countries and then I was just like: 'oh wait, I've never stayed somewhere for more than two weeks before'. So I like to be more fully immersed in the culture and getting used the day-to-day activities, like going to work, going to the grocery store, doing this and that, and getting to know people, and getting to know the culture, and getting to know everything as opposed to just going to the a city for three days and seeing the major attractions and then leaving and going to another city.

Amy underlines and contrasts her 'living' experience in Lima from that of 'visiting' or 'travelling' to distinguish her current sojourn not only from her previous travel experiences, but also from those of passing travellers and shorter-term visitors. Brianne shares the same perspective:

I think it was the idea of living there that was the best part, because again, I've never lived abroad. I had only been passing through travelling.... I'm also proud of myself that I was able to really live.

Brianne highlights this sense of achievement in having 'lived' in a place abroad instead of 'passing' by as she had done in prior travels. The emphasis on the living rather than visiting suggests an ability to cope with everyday challenges in the Global South that tourists would normally not encounter during brief sightseeing tours. This apparent accomplishment and status 
as a 'local', as well as all the everyday challenges that their status implies, grants participants a perceived membership to the local society and with that a sense of distinction. Participants feel they have been upgraded from the category of 'international traveller' to the more exclusive membership of a 'local insider' in a specific place abroad. Such narratives suggest that a relative immobility while abroad affords a more unique form of cultural capital and hence, signals the acquisition of a rarer symbolic capital - at least among Canadian and Western peers. Amidst a society and generation of well-travelled youth, participants seem to portray their international exchange sojourn as a distinctive 'lived' experience of home-making in order to collect 'homes' for distinction. I therefore argue that home-making at the scale of the city may simultaneously be a process of defining spatial urban boundaries for distinction-making.

\section{Conclusion}

This paper explored the home-making practices of international exchange students' during their sojourn in the Global South. It adds to emerging research on home-making practices within student geographies but extends this scholarship by exploring how 'home' is created within international student mobility. In doing so, it contributes to debates about home, belonging and everyday practices which are virtually absent within international student mobility. The findings demonstrated that even within short-term sojourns abroad, international exchange students actively engage in home-making practices in their host city. The notions of familiarity and everyday places and practices are shown to play a constructive role within the process of homemaking and belonging while abroad. Students engage with local practices, places and people in order to become familiar with, and accumulate geographical knowledge of, their new city as a way of developing a sense of belonging and 'home'. While I acknowledge the critical geographies of 'home' that make space for instances and presences of unfamiliarity and strangeness (Ahmed, 1999), I have shown that familiarity mediates and creates feelings of belonging and homeliness for exchange students in the Global South. Students favour coffee shops and other local mundane public places that are frequented mainly by locals to gain insider knowledge and integrate into the local community. This insider knowledge of the new place, as I argued, is used by students to legitimise claims of belonging and 'home' to their host city.

The findings not only illustrate that students attach a sense of belonging to everyday places and spaces, but that students identify their host city - and in some cases specific neighbourhoods - rather than the country, as a knowable and familiar home-place. In fact, this paper challenges scalar and conceptual notions of 'home' at the scale of the nation and supports recent studies that downscale and reconceptualise 'home' to the space of the city (Blunt \& Bonnerjee, 2013; Lahiri, 2010). I thus demonstrated that despite some claims of belonging to the nation, most students focalise and localise their claims of 'home' and belonging to the city. I argued alongside Blunt and Bonnerjee (2013) that even for exchange students, a sense of belonging and 'home' is located in both the host and 'home' cities. Participants seek to tighten the spatial boundaries of 'home' in what seems to be both a practical and strategic undertaking. Practically, an urban space presents a more feasible space to explore and familiarise oneself with than a country. Strategically, laying claims of belonging and insider knowledge to a city is more realistic and conceivable than to a nation. As such, rather than compete for symbolic capital with higher numbers of visitors who have travelled to and within the same nation, I suggested that students deliberately localise their home-making practices and narratives of 'home' and belonging to the city in order to appropriate a more unique space for cultural capital gains. Many people have travelled to a particular nation but less are likely to have visited and resided in a particular city and as such, fewer visitors to a particular place allows the new 'insider' to maintain exclusive claims of belonging and authoritative knowledge of their new 'home-place' over other (Western) travellers. Thus, this paper has demonstrated that 
home-making is tied up in a process of scalar boundary-making to strategically delimit knowable and familiar spaces for spatial and social claims of belonging within the city. It has shown that students draw imaginary borders around specific urban spaces to define unique spatially embedded cultural capital. In doing so, the paper builds on Datta (2011) and Blunt and Bonnerjee's (2013) conceptualisations of 'home' as tied to everyday practices and cultural capital within the city. I therefore advance scholarship on mobile geographies of 'home' and international student mobility by arguing that home-making practices and narratives of 'home' are implicated in scalar and spatial boundary-making processes of distinction-making. This has wider relevance beyond the context of international students for understanding how the idea of 'home' can be strategically deployed in narratives of distinction.

The findings demonstrate how reciprocal greeting gestures in the street as well as being mistaken for a local native speaker endows students with a sense of belonging and legitimises their claims to being an insider. These claims of 'home' and insiderness are further reinforced through emphasising their 'living' rather than 'visiting' status in relation to the different actors in that space. Participants compare their day-to-day participation in everyday local practices and public places as similar to those of locals while distinguishing their working or studying purpose from the leisure purposes of shorter-term tourists and travellers. Although the line drawn between work/study and leisure is evidently ambiguous as participants do travel and sightsee within and outside their host country, this is significant as I argue that it is their relative immobility while abroad which is used to narrate local belonging and signal distinction (Prazeres, 2016). Narratives and practices of home-making while abroad are thus implicated in processes of inclusion and exclusion that inevitably reproduces social advantage upon return to the 'home' country.

Based on Desforges' (1998) 'collecting places', this paper has argued that students are 'collecting homes' through the various places they have lived. This collection of 'homes' signals an accumulation of a more place-specific capital that can be narrated to friends and family both during their sojourn and upon return. While 'collecting places' is based on 'a representation of the world as a series of differences from home' (Desforges, 1998, p. 178), in this study, 'collecting homes' is about feeling 'at home' in specific cities around the world and framing these urban places as 'home', rather than different to home. I suggest that 'collecting homes' through insider knowledge and place-specific capital signals to peers and friends in Canada the ability to engage with and get into the nitty-gritty of everyday urban life in the Global South, rather than skip or skim the 'messy' mundane bits by travelling through as a tourist. Importantly, it is the inherent postcolonial imaginaries and power geometries of voluntary mobility to the Global South that enable international students' distinction-making. Despite the localised experiences of 'home' abroad, I argue that international borders do not become irrelevant; rather, local home-making practices are situated within an international context in which local cultural capital is projected onto a global (South) backdrop.

Finally, I highlight the need to extend scholarship on geographies of 'home' to international student mobility. Future research should take a closer look at how students collect 'homes' and how these multiple homely (urban) places are incorporated and integrated into longer-term meanings of 'home' and may be used later in the life course as resources within discourses of distinction. This includes considering how the privilege that is reproduced through their mobility also allows them to collect 'homes' comfortably. I encourage future research to consider the everyday life of students abroad and how ideas of 'home' are challenged and potentially changed through mundane practices and daily encounters with new places and people. I also recommend using visual methodologies, such as participant-directed photography as an effective tool to illustrate and elicit both the everyday and extra/ordinary places, events and people that punctuate, fracture and pervade international students' everyday lives and meanings of 'home'. 


\section{References:}

Ahmed, S. (1999). Home and away. International Journal of Cultural Studies, 2, 329-347.

Ahmed, S., Castañeda, C., Fortier, A-M. \& Sheller, M. (Eds.). (2003). Uprootings/Regroundings: Questions of Home and Migration. Oxford: Berg.

Anderson, V. R. (2012). 'Homes' and being 'at home' in New Zealand. Gender, Place and Culture, 19, 327-343.

Antonsich, M. (2010). Searching for Belonging - An Analytical Framework. Geography Compass, 4, 644-659.

Benson, M. (2010). 'We are Not Expats; We are Not Migrants; We are Sauliacoise'. In C. Trundle and B. Bönisch-Brednich (Eds.), Local Lives: Migration and the Politics of Place (pp. 67-83). Farnham: Ashgate.

Blunt, A. \& Bonnerjee, J. (2013). Home, city and diaspora. Global Networks, 13, 220-240.

Blunt, A. \& Dowling, R. (2006). Home. London: Routledge.

Breen, M. (2012). Privileged migration: American undergraduates, study abroad, academic tourism. Critical Arts, 26, 82-102.

Brooks, R., Waters, J. \& Pimlott-Wilson, H. (2012). International Education and the Employability of UK Students. British Educational Research Journal, 38, 281-298.

Case, D. (1996). Contributions of journeys away to the definition of home. Journal of Environmental Psychology, 16, 1-15.

Collins, F. L. (2009). Connecting 'Home' With 'Here'. Journal of Ethnic and Migration Studies, 35, 839-859.

Cook, A. C. G. (2011). Placing capital(s): everyday social transformations of transnational elites in Prague, Czech Republic. Area, 43, 420-429.

Cresswell, T. (2010). Towards a politics of mobility. Environment and Planning D, 28, 17-31.

Datta, A. (2011). Translocal Geographies of London. In K. Brickell and A. Datta (Eds.), Translocal Geographies: Spaces, Places, Connections (pp. 73-91). Farnham: Ashgate.

Desforges, L. (1998). 'Checking Out the Planet'. In T. Skelton and G. Valentine (Eds.), Cool Places: geographies of youth cultures (pp. 175-192). London: Routledge.

Dodman, D. R. (2003). Shooting in the city: an autophotographic exploration of the urban environment in Kingston, Jamaica. Area, 35, 293-304.

Edensor, T. (2007). Mundane mobilities, performances and spaces of tourism. Social \& Cultural Geography, 8, 199-215.

Findlay, A. M., King, R., Smith, F. M., Geddes, A. \& Skeldon, R. (2012). World class? An investigation of globalisation, difference and international student mobility. Transactions of the Institute of British Geographers, 37, 118-131.

Germann Molz, J. (2008). Global Abode: Home and Mobility in Narratives of Round-the-World Travel. Space and Culture, 11, 325-342.

Gilmartin, M. (2008). Migration, Identity and Belonging. Geography Compass, 2, 1837-1852.

Hinton, D. (2011). 'Wales is my home': higher education aspirations and student mobilities in Wales. Children's Geographies, 9, 23-34.

Holdsworth, C. (2009). 'Going away to uni'. Environment and Planning A, 41, 1849-1864.

Holton, M. \& Riley, M. (2016). Student geographies and homemaking. Social \& Cultural Geography, 17, 623-645.

Kellett, P. \& Moore, J. (2003). Routes to home. Habitat International, 27, 123-141.

Kenyon, L. (1999). A Home from Home. In T. Chapman and J. Hockey (Eds.), Ideal Homes? Social change and domestic life (pp. 84-95). London: Routledge.

King, R., Findlay, A., Ahrens, J. \& Dunne, M. (2011). Reproducing advantage: the perspective of English school leavers on studying abroad. Globalisation, Societies and Education, 9, 161-181. 
Lahiri, S. (2010). At home in the city, at home in the world. Contemporary South Asia, 18, 191204.

Madge, C., Raghuram, P. and Noxolo, P. (2009). Engaged Pedagogy and Responsibility: A Postcolonial Analysis of International Students. Geoforum, 40, 34-45.

Mallett, S. (2004). Understanding home: a critical review of the literature. The Sociological Review, 52, 62-89.

Munt, I. (1994). The 'Other' Postmodern Tourism. Theory, Culture \& Society, 11, 101-123.

Murphy-Lejeune, E. (2002). Student Mobility and Narrative in Europe: The new strangers. London: Routledge.

Nowicka, M. (2007). Mobile locations: construction of home in a group of mobile transnational professionals. Global Networks, 7, 69-86.

Pauwels, L. (2011). An Intergrated Conceptual Framework for Visual Social Research. In E. Margolis and L. Pauwels (Eds.), The SAGE Handbook of Visual Research Methods. (pp. 3-23), London, SAGE.

Pink, S. (2006). Visual methods. In V. Jupp (Ed.), The Sage Dictionary of Social and Research Methods (pp. 320-322). London: SAGE.

Prazeres, L. (2016). Challenging the comfort zone: self-discovery, everyday practices and international student mobility to the Global South. Mobilities.

Ralph, D. and Staeheli, L. A. (2011). Home and Migration. Geography Compass, 5, 517-530.

Rapport, N. and Dawson, A. (1998). Migrants of Identity: Perceptions of Home in a World of Movement. Oxford, Berg: 246.

Rose, G. (2008). Using Photographs as Illustrations in Human Geography. Journal of Geography in Higher Education, 32, 151-160.

Salisbury, M. H., Paulsen, M. B. and Pascarella, E. T. (2010). To See the World or Stay at Home. Research in Higher Education, 51, 615-640.

Skey, M. (2011). 'Thank god, I'm back!': (Re)defining the nation as a homely place in relation to journeys abroad. Journal of Cultural Geography, 28, 233-252.

Snee, H. (2013). Framing the Other: cosmopolitanism and the representation of difference in overseas gap year narratives. The British Journal of Sociology, 64, 142-162.

Valentine, G. (2001). Social Geographies: space and society. New York, NY: Prentice Hall.

Waters, J. (2012). Geographies of International Education. Geography Compass, 6, 123-136.

Waters, J. and Brooks, R. (2010). Accidental achievers? International higher education, class reproduction and privilege in the experiences of UK students overseas. British Journal of Sociology of Education, 31, 217-228.

Waters, J., Brooks, R. \& Pimlott-Wilson, H. (2011). Youthful escapes? British students, overseas education and the pursuit of happiness. Social \& Cultural Geography, 12, 455469.

Waters, J. \& Leung, M. (2013). Immobile Transnationalisms? Young People and Their in situ Experiences of 'International' Education in Hong Kong. Urban Studies, 50, 606-620.

Wiles, J. (2008). Sense of home in a transnational social space. Global Networks, 8, 116-137. Yuval-Davis, N. (2006). Belonging and the politics of belonging. Patterns of Prejudice, 40, 197214. 